\title{
Sports in Gaining Life Skills: A Study on 10-14 Years Old Students
}

\author{
Tamer Karademir
}

Kahramanmaraş Sütçü Imam University, School of Physical Education and Sports, Kahramanmaraş, Turkey. Email:tamer.karademir@hotmail.com Tel: +903443002196

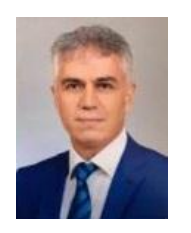

\begin{abstract}
The study aims to investigate how the participation of secondary school students in sportive activities affects their life skills. For this purpose, the study included 708 voluntary students, 396 males, and 312 females, in the 2019-2020 education period. In the study, the Life Skills Scale for Sport (LSSS) was used as the data collection tool to evaluate the levels of life skills. To analyze the data collected in the study, SPSS 21 statistics package software was used. The data were analyzed for normality. As a result of the tests, because it was observed that the data did not have normality distribution, non-parametric tests were utilized. For two-sample comparisons, the Mann Whitney U test was used while the Kruskal Wallis $\mathrm{H}$ test was utilized for multiple-sample comparisons. In the study, the level of significance was regarded as $\mathrm{p}<0.05$. The findings of the study indicated that there were significant differences in the life skill levels of the sample group according to the variables of age, gender, grade, the status of exercising and playing in school teams. In conclusion, it was concluded that the life skill levels of 14-year-old students (communication, time management, leadership, teamwork, emotional skills, and social skills) were high while sportive activities were more effective on female students at this age interval compared to male students. It was also observed that participating in school teams enabled positive gains on life skills.
\end{abstract}

Keywords: Sport, Education, Life skills, Children, Schools, Turkey.

Citation | Tamer Karademir (2020). Sports in Gaining Life Skills: A Study on 10-14 Years Old Students. Asian Journal of Education and Training, 6(3): 485-492.

History:

Received: 1 May 2020

Revised: 15 June 2020

Accepted: 8 July 2020

Published: 20 July 2020

Licensed: This work is licensed under a Creative Commons

Licensed: This work is

Publisher: Asian Online Journal Publishing Group
Funding: This study received no specific financial support.

Competing Interests: The author declares that there are no conflicts of interests regarding the publication of this paper.

Transparency: The author confirms that the manuscript is an honest, accurate, and transparent account of the study was reported; that no vital features of the study have been omitted; and that any discrepancies from the study as planned have been explained.

Ethical: This study follows all ethical practices during writing.

\section{Contents}

1. Introduction

2. Material and Method

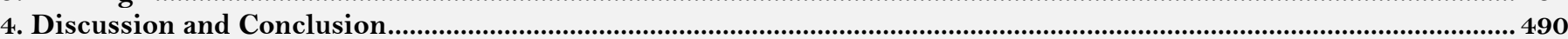

References. 


\section{Contribution of this paper to the literature}

This study contributes to the existing literature by investigating how the participation of secondary school students in sportive activities affects their life skills.

\section{Introduction}

Numerous studies in the field of sports indicated that sportive activities shaped and developed personality and character structures while providing improvements to physical and mental health in addition to effecting individuals in gaining positive behaviors in the individual and social field (Caterino \& Polak, 1999; Larson, 2000).

During the education period, which starts from the preschool period and continues up to the university period, participation in physical education and sports provides children with significant contributions in social, emotional, mental, and physical terms.

In this period, the first expectation from physical education and sports lessons is to assume supportive and guiding roles in providing students with active and healthy life skills by developing their physical competence levels. Additionally, physical education and sports lessons are expected to develop self-control, adaptation to the social environment, and cognitive skills as well (Açak 2006). Sport is a performance science that supports the development of individuals in physical and psychosocial terms (Tel \& Köksalan, 2008).

The World Health Organization defines life skills as practical psychosocial skills that facilitate individuals to gain self-confidence and to socialize and emphasizes that they affect the healthy development of young individuals (World Health Organization, 1999).

Life skills have an important place in individuals because they are related to various situations such as health, education, sports, culture, arts, and business life. Researchers stated that life skills are significant determiners in individuals' lives and they were effective in various conditions such as general health status (Claessens, van Eerde, Rutte, \& Roe, 2007) psychological well-being (Judge, Bono, Erez, \& Locke, 2005) academic achievement (Humphrey et al., 2011) sports and exercise performance (Burton, Naylor, \& Holliday, 2001) workplace efficiency and success (Rubin \& Morreale, 1996). Furthermore, life skills, which provide opportunities to deal with problems experienced in the adolescence period in more effective and healthier ways, should be emphasized in terms of supporting physical, mental and social developments of individuals and becoming more successful by protecting individuals from harmful habits such as alcohol, cigarette, and drugs (Botvin \& Griffin, 2004).

Social skills, which are placed in life skills, can be stated as certain behaviors that are specifically developed to meet children's physical and intellectual needs without experiencing problems in the social field (Onder, 2003). Accordingly, social skills state teachable behaviors that facilitate the participation of individuals in societies and that help them establish their communication with societies while improving their academic performance, teaching how to take their bodies and emotions under control, and covering cognitive and affective skills such as adaptation and assertiveness. Social skills, which can be stated as skills to adapt to social environments, assume a significant duty in terms of shaping interpersonal relationships and achieving social aims (Avcioğlu, 2005).

Numerous findings, such as social skills (Gould, Flett, \& Lauer, 2012) emotional skills (Brunelle, Danish, \& Forneris, 2007) cognitive skills (Danish, Forneris, Hodge, \& Heke, 2004) communication skills (Gould, Collins, Lauer, \& Chung, 2007) teamwork (Holt, 2007) leadership (Camiré, Trudel, \& Forneris, 2009) time management (Fraser-Thomas \& Côté, 2009) taking initiative, respecting others and setting goals (Holt, Tink, Mandigo, \& Fox, 2008) finding solutions to problems and decision making (Strachan, Côté, \& Deakin, 2011) emphasize the place of sports in developing certain life skills. In any group of professions, developing individuals' communication skills can make the process of communication healthier. The necessity of having such skills in groups of professions which cover intense human relationships is inevitable. Physical education professionals, coaches, and sports managers, who serve in sportive activities, should have these skills. Furthermore, humans, which have a will to act in their nature and communicate in this way, can ensure that interpersonal relationships are healthy and continuous by participating in sports activities.

Findings of sports' effect on individuals, such as developing teamwork, setting goals, taking initiative, respecting others, time management, cognitive skills, emotional skills, communicative skills, social skills, leadership, problem-solving, and decision making, reveal the necessity to place more importance on this subject. Accordingly, the current study was conducted to reveal how the participation of secondary schools in sports shapes their life skill levels according to the variables that were discussed.

\section{Material and Method \\ 2.1. Study Group}

The sample of the study consisted of 708 individuals (396 males and 312 females), who studied in secondary schools $\left(5^{\text {th }}, 6^{\text {th }}, 7^{\text {th }}\right.$ and $8^{\text {th }}$ grades $)$ in the central county of the city of Kahramanmaras in the 2019-2020 education period. For the study, the required permissions were obtained from the parents of the students and the government agencies. To determine the size of the sample in the study, the "Number of individuals in the population known sample size formula" ( $\mathrm{n}=\mathrm{Nt} 2 \mathrm{pq} / \mathrm{d} 2(\mathrm{~N}-1)+\mathrm{t} 2 \mathrm{pq}$ ) was used. While calculating the sample size, $\alpha=0.05$ was regarded as the error level while 0.05 was regarded as the sampling error in addition to $p=0.8$ and $q=0.2$. The study covered students who were chosen by the simple random sampling method and who accepted to participate in the study.

\subsection{Data Collection Tools}

The data in the study were collected by the Life Skills Scale for Sport in addition to the personal information.

\subsection{Life Skills Scale for Sport}

To evaluate the life skills obtained through sports, the authentic form, the Life Skills Scale for Sport (LSSS), was developed by Cronin and Allen in 2017 as a 5-point Likert-type scale (Cronin \& Allen, 2017). The scale can be conducted with secondary school, high school, and university students up to 21 years olds. The validity and reliability study of the scale in Turkish was conducted by Açak and Düz (2018) while the scale consisted of 31 
items and 7 subscales, which covered teamwork, goal setting, time management, emotional skills, communication, social skills, and leadership. The items in the scale are scored with a 5-point Likert-type scale, which ranges from "Strongly Disagree" (1 point) to "Strongly Agree" (5 points). In our study, the reliability coefficients were determined as 0.90 of Cronbach's Alpha coefficient for Time Management (items 1, 2, 3, and 4), 0.92 of Cronbach's Alpha coefficient for Communication (items 5, 6, 7, and 8), 0.91 of Cronbach's Alpha coefficient for Leadership (items 9, 10, 11, 12 and 13), 0.88 of Cronbach's Alpha coefficient for Teamwork (items 14, 15, 16, 17, 18 and 19), 0.89 of Cronbach's Alpha coefficient for Social Skills (items 20, 21, 22, and 23), 0.93 of Cronbach's Alpha coefficient for Emotional Skills (items 24, 25, 26 and 27), and 0.92 of Cronbach's Alpha coefficient for Goal Setting (Items 28, $29,30$, and 31$)$. In the scoring of items in the scale, no item was reverse scored.

\subsection{Data Analysis}

To analyze the data obtained as a result of the study, SPSS 21 statistics package software was used. Before the statistical analysis, Shapiro-Wilks and Kolmogorov-Smirnov normality analysis tests were conducted to test whether the data had a normal distribution and whether it was homogenous. As a result of the tests, it was observed that the data did not have a normal distribution. Thus, non-parametric tests were utilized for the analyses. For the two-sample comparisons of the independent variables, the Mann Whitney U test was used while the Kruskal Wallis H test was used for multiple-sample comparisons. In the multiple-sample comparative analyses, Mann Whitney U test- which is a non-parametric test used for detecting the source of difference where differences exist, was conducted. The level of confidence in the study was regarded as $\mathrm{p}<0.05$.

\section{Findings}

The data obtained from the study group were analyzed and presented in the tables below.

Table-1. Variables of age, gender, grade, family income level, playing in school teams of the study group.

\begin{tabular}{|c|c|c|c|}
\hline \multicolumn{2}{|c|}{ Age } & \multirow{2}{*}{$\frac{\mathbf{n}}{112}$} & \multirow{2}{*}{$\begin{array}{c}\% \\
15.8\end{array}$} \\
\hline & 10 & & \\
\hline & 11 & 132 & 18.7 \\
\hline & 12 & 180 & 25.4 \\
\hline & 13 & 164 & 23.2 \\
\hline & 14 & 120 & 16.9 \\
\hline & Total & 708 & 100.0 \\
\hline \multicolumn{2}{|c|}{ Gender } & $\mathrm{n}$ & $\%$ \\
\hline & Male & 396 & 55.9 \\
\hline & Female & 312 & 44.1 \\
\hline & Total & 708 & 100.0 \\
\hline \multicolumn{2}{|c|}{ Grade } & $\mathrm{n}$ & $\%$ \\
\hline & $5^{\text {th }}$ Grade & 164 & 23.2 \\
\hline & $6^{\text {th }}$ Grade & 182 & 25.7 \\
\hline & $7^{\text {th }}$ Grade & 180 & 25.4 \\
\hline & $8^{\text {th }}$ Grade & 182 & 25.7 \\
\hline & Total & 708 & 100.0 \\
\hline \multicolumn{2}{|c|}{ Family Income Level } & $\mathrm{n}$ & $\%$ \\
\hline & Low & 123 & 17.4 \\
\hline & Moderate & 181 & 25.5 \\
\hline & High & 234 & 33.1 \\
\hline & Very High & 170 & 24 \\
\hline & Total & 708 & 100.0 \\
\hline \multicolumn{2}{|c|}{ Exercising Status } & $\mathrm{n}$ & $\%$ \\
\hline & Yes & 346 & 48.9 \\
\hline & No & 362 & 51.1 \\
\hline & Total & 708 & 100 \\
\hline \multicolumn{2}{|c|}{ Playing in School Teams } & $\mathrm{n}$ & $\%$ \\
\hline & Yes & 203 & 28.7 \\
\hline & No & 505 & 71.3 \\
\hline & Total & 708 & 100.0 \\
\hline
\end{tabular}

According to Table 1, it was determined that $15.8 \%$ of the study group consisted of 10-years-old students while $28.7 \%$ of them were 11 years old in addition to $25.4 \%$ of the participants who were 12 years old, $23.2 \%$ of the participants who were 13 years old, and $16.9 \%$ of the participants who were 14 years old. Additionally, $55.9 \%$ of the study group covered male students while $44.1 \%$ of them were females. In terms of the grade levels, $23.2 \%$ of the study group studied in $5^{\text {th }}$ grade while $25.7 \%$ of them studied in $6^{\text {th }}$ grade in addition to $25.4 \%$ of the participants who studied in $7^{\text {th }}$ grade and $25.7 \%$ of the participants who studied at $8^{\text {th }}$ grade. In terms of the income levels of the families, $17.4 \%$ of the study group had families with low-income levels while 25.5 of the study group had families with moderate income levels in addition to $33.1 \%$ of the participants who had families with high-income levels and $24 \%$ of participants who had families with very high-income levels. It was further determined that $48.9 \%$ of the study group participated in sports while $51.1 \%$ of them did not exercise. Additionally, it was determined that $28.7 \%$ of the participants played in school teams while $71.3 \%$ of the participants did not play in school teams. 


\begin{tabular}{|c|c|c|c|c|c|c|c|}
\hline Age & & $\mathbf{N}$ & Mean & SD & $\mathrm{X}^{2}$ & $\mathrm{p}$ & Difference U test \\
\hline \multirow{5}{*}{ Time Management } & 10 & 112 & 14.22 & 3.39 & \multirow{5}{*}{22.520} & \multirow{5}{*}{$.000^{*}$} & \multirow{5}{*}{$5>1,2,3,4$} \\
\hline & 11 & 132 & 14.27 & 3.43 & & & \\
\hline & 12 & 180 & 15.10 & 3.59 & & & \\
\hline & 13 & 164 & 15.62 & 2.28 & & & \\
\hline & 14 & 120 & 17.47 & 2.74 & & & \\
\hline \multirow{5}{*}{ Communication } & 10 & 112 & 15.07 & 3.00 & \multirow{5}{*}{9.38} & \multirow{5}{*}{$.022 *$} & \multirow{5}{*}{$5>1,2,3,4$} \\
\hline & 11 & 132 & 15.33 & 3.12 & & & \\
\hline & 12 & 180 & 15.17 & 3.32 & & & \\
\hline & 13 & 164 & 15.46 & 3.39 & & & \\
\hline & 14 & 120 & 16.69 & 3.56 & & & \\
\hline \multirow{5}{*}{ Leadership } & 10 & 112 & 16.23 & 4.21 & \multirow{5}{*}{1.704} & \multirow{5}{*}{$.002 *$} & \multirow{5}{*}{$5>1,2,3,4$} \\
\hline & 11 & 132 & 16.41 & 3.05 & & & \\
\hline & 12 & 180 & 16.68 & 4.23 & & & \\
\hline & 13 & 164 & 16.99 & 4.26 & & & \\
\hline & 14 & 120 & 18.21 & 4.91 & & & \\
\hline \multirow{5}{*}{ Teamwork } & 10 & 112 & 22.66 & 4.94 & \multirow{5}{*}{20.943} & \multirow{5}{*}{$.000^{*}$} & \multirow{5}{*}{$5>1,2,3,4$} \\
\hline & 11 & 132 & 22.54 & 4.42 & & & \\
\hline & 12 & 180 & 22.57 & 4.28 & & & \\
\hline & 13 & 164 & 22.92 & 4.20 & & & \\
\hline & 14 & 120 & 24.67 & 4.43 & & & \\
\hline \multirow{5}{*}{ Social Skills } & 10 & 112 & 14.22 & 3.43 & \multirow{5}{*}{18.643} & \multirow{5}{*}{$.002^{*}$} & \multirow{5}{*}{$5>1,2,3,4$} \\
\hline & 11 & 132 & 14.36 & 3.32 & & & \\
\hline & 12 & 180 & 14.65 & 3.34 & & & \\
\hline & 13 & 164 & 14.57 & 3.76 & & & \\
\hline & 14 & 120 & 16.88 & 3.37 & & & \\
\hline \multirow{5}{*}{ Emotional Skills } & 10 & 112 & 14.67 & 3.10 & \multirow{5}{*}{14.645} & \multirow{5}{*}{$.009 *$} & \multirow{5}{*}{$5>1,2,3,4$} \\
\hline & 11 & 132 & 14.49 & 3.29 & & & \\
\hline & 12 & 180 & 14.32 & 3.22 & & & \\
\hline & 13 & 164 & 14.68 & 3.93 & & & \\
\hline & 14 & 120 & 15.68 & 4.44 & & & \\
\hline \multirow{5}{*}{ Goal Setting } & 10 & 112 & 15.47 & 2.54 & \multirow{5}{*}{13.154} & \multirow{5}{*}{$.013^{*}$} & \\
\hline & 11 & 132 & 15.43 & 3.68 & & & \\
\hline & 12 & 180 & 15.67 & 3.47 & & & $5>1,2,3,4$ \\
\hline & 13 & 164 & 15.88 & 3.02 & & & \\
\hline & 14 & 120 & 16.89 & 3.36 & & & \\
\hline
\end{tabular}

According to Table 2, in the analyses conducted for the variable of age in the study group, it was determined that the differences in all of the subscales of life skills for sports were statistically significant $(\mathrm{p}<0.05)$.

Table-3. Analysis results of the study group according to the variable of gender (Mann Whitney U Test).

\begin{tabular}{|c|c|c|c|c|c|c|}
\hline \multicolumn{2}{|l|}{ Gender } & $\mathbf{N}$ & Mean & SD & $\bar{Z}$ & $\bar{p}$ \\
\hline \multirow{2}{*}{ Time Management } & Male & 396 & 14,65 & 3,29 & \multirow{2}{*}{$-3,454$} & \multirow{2}{*}{,013* } \\
\hline & Female & 312 & 16,89 & 3,23 & & \\
\hline \multirow{2}{*}{ Communication } & Male & 396 & 14,35 & 3,20 & \multirow{2}{*}{$-2,278$} & \multirow{2}{*}{,031* } \\
\hline & Female & 312 & 15,76 & 3,35 & & \\
\hline \multirow{2}{*}{ Leadership } & Male & 396 & 16,24 & 3,58 & \multirow{2}{*}{$-2,802$} & \multirow{2}{*}{,023* } \\
\hline & Female & 312 & 18,04 & 3,64 & & \\
\hline \multirow{2}{*}{ Teamwork } & Male & 396 & 22,52 & 3,37 & \multirow{2}{*}{$-2,547$} & \multirow{2}{*}{,034* } \\
\hline & Female & 312 & 24,73 & 4,34 & & \\
\hline \multirow{2}{*}{ Social Skills } & Male & 396 & 14,67 & 3,34 & \multirow{2}{*}{$-3,656$} & \multirow{2}{*}{, $011^{*}$} \\
\hline & Female & 312 & 15,98 & 3,20 & & \\
\hline \multirow{2}{*}{ Emotional Skills } & Male & 396 & 14,43 & 3,25 & \multirow{2}{*}{$-3,832$} & \multirow{2}{*}{, $002^{*}$} \\
\hline & Female & 312 & 15,72 & 3,05 & & \\
\hline \multirow{2}{*}{ Goal Setting } & Male & 396 & 14,28 & 3,44 & \multirow{2}{*}{$-2,439$} & \multirow{2}{*}{, $017^{*}$} \\
\hline & Female & 312 & 16,95 & 3,28 & & \\
\hline
\end{tabular}

According to Table 3, in the analyses conducted for the variable of gender in the study group, it was determined that the differences in all of the subscales of life skills for sports were statistically significant $(\mathrm{p}<0.05)$.

According to Table 4, in the analyses conducted for the variable of grade in the study group, it was determined that the differences in all of the subscales of life skills for sports were statistically significant $(\mathrm{p}<0.05)$. 
Table-4. Analysis results of the study group according to the variable of grade (Kruskal Wallis H Test)

\begin{tabular}{|c|c|c|c|c|c|c|c|}
\hline Grade & & $\mathbf{N}$ & Mean & SD & $\mathbf{X}^{2}$ & $\bar{p}$ & Difference U test \\
\hline \multirow{4}{*}{ Time Management } & $5^{\text {th }}$ Grade & 164 & 14.34 & 3.39 & \multirow{4}{*}{23.309} & \multirow{4}{*}{$.000^{*}$} & \multirow{4}{*}{$4>1,2,3$} \\
\hline & $6^{\text {th }}$ Grade & 182 & 14.65 & 3.85 & & & \\
\hline & $7^{\text {th }}$ Grade & 180 & 14.70 & 3.62 & & & \\
\hline & $8^{\text {th }}$ Grade & 182 & 16.58 & 3.24 & & & \\
\hline \multirow{4}{*}{ Communication } & $5^{\text {th }}$ Grade & 164 & 14.37 & 3.15 & \multirow{4}{*}{18.454} & \multirow{4}{*}{$.002^{*}$} & \multirow{4}{*}{$4>1,2,3$} \\
\hline & $6^{\text {th }}$ Grade & 182 & 14.31 & 3.25 & & & \\
\hline & $7^{\text {th }}$ Grade & 180 & 14.48 & 3.43 & & & \\
\hline & $8^{\text {th }}$ Grade & 182 & 15.69 & 3.12 & & & \\
\hline \multirow{4}{*}{ Leadership } & $5^{\text {th }}$ Grade & 164 & 16.65 & 3.21 & \multirow{4}{*}{14.643} & \multirow{4}{*}{$.025^{*}$} & \multirow{4}{*}{$\begin{array}{c}4>1,2,3 \\
3>1,2\end{array}$} \\
\hline & $6^{\text {th }}$ Grade & 182 & 16.78 & 3.38 & & & \\
\hline & $7^{\text {th }}$ Grade & 180 & 17.04 & 4.94 & & & \\
\hline & $8^{\text {th }}$ Grade & 182 & 17.85 & 4.12 & & & \\
\hline \multirow{4}{*}{ Teamwork } & $5^{\text {th }}$ Grade & 164 & 22.23 & 4.08 & \multirow{4}{*}{17.064} & \multirow{4}{*}{$.003^{*}$} & \multirow{4}{*}{$4>1,2,3$} \\
\hline & $6^{\text {th }}$ Grade & 182 & 22.26 & 4.55 & & & \\
\hline & $7^{\text {th }}$ Grade & 180 & 22.39 & 4.36 & & & \\
\hline & $8^{\text {th }}$ Grade & 182 & 23.63 & 4.71 & & & \\
\hline \multirow{4}{*}{ Social Skills } & $5^{\text {th }}$ Grade & 164 & 14.52 & 3.40 & \multirow{4}{*}{16.759} & \multirow{4}{*}{$.004 *$} & \multirow{4}{*}{$4>1,2,3$} \\
\hline & $6^{\text {th }}$ Grade & 182 & 14.87 & 3.26 & & & \\
\hline & $7^{\text {th }}$ Grade & 180 & 14.58 & 3.82 & & & \\
\hline & $8^{\text {th }}$ Grade & 182 & 15.77 & 3.40 & & & \\
\hline \multirow{4}{*}{ Emotional Skills } & $5^{\text {th }}$ Grade & 164 & 14.81 & 3.16 & \multirow{4}{*}{11.538} & \multirow{4}{*}{$.017^{*}$} & \multirow{4}{*}{$4>1,2,3$} \\
\hline & $6^{\text {th }}$ Grade & 182 & 14.68 & 3.32 & & & \\
\hline & $7^{\text {th }}$ Grade & 180 & 14.98 & 3.79 & & & \\
\hline & $8^{\text {th }}$ Grade & 182 & 15.66 & 4.26 & & & \\
\hline \multirow{4}{*}{ Goal Setting } & $5^{\text {th }}$ Grade & 164 & 15.47 & 3.95 & \multirow{4}{*}{13.642} & \multirow{4}{*}{$.013^{*}$} & \multirow{4}{*}{$4>1,2,3$} \\
\hline & $6^{\text {th }}$ Grade & 182 & 15.40 & 3.05 & & & \\
\hline & $7^{\text {th }}$ Grade & 180 & 15.49 & 3. & & & \\
\hline & $8^{\text {th }}$ Grade & 182 & 16.78 & 3.83 & & & \\
\hline
\end{tabular}

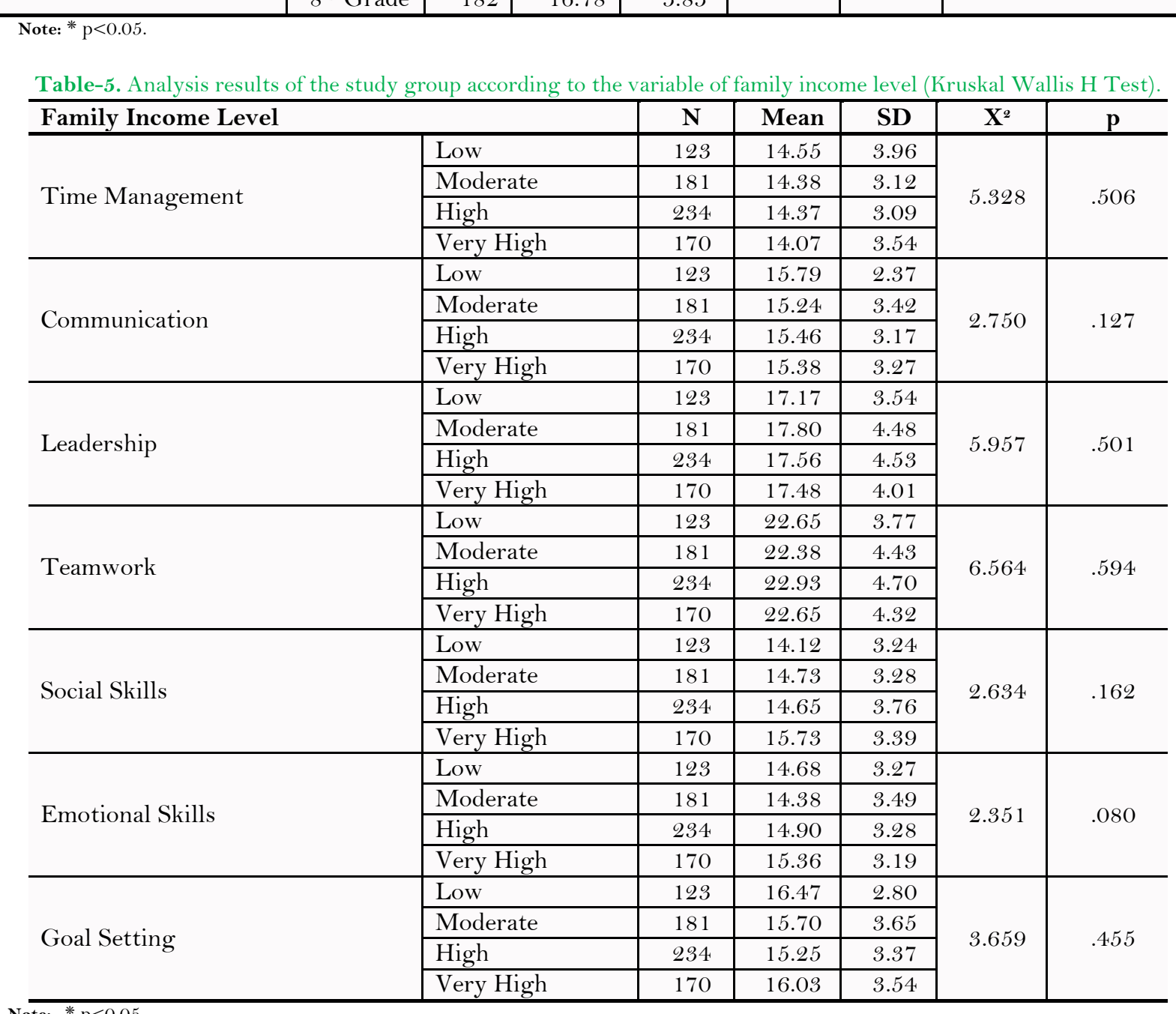

Note: ${ }^{*} \mathrm{p}<0.05$

According to Table 5, in the analyses conducted for the variable of family income level in the study group, it was determined that the differences in all of the subscales of life skills for sports were not statistically significant $(\mathrm{p}>0.05)$.

According to Table 6, in the analyses conducted for the variable of exercising status in the study group, it was determined that the differences in all of the subscales of life skills for sports were statistically significant $(\mathrm{p}<0.05)$. 
Table-6. Analysis results of the study group according to the variable of exercising status (Mann Whitney U Test).

\begin{tabular}{|c|c|c|c|c|c|c|}
\hline Exercising Status & & $\mathbf{N}$ & Mean & SD & $\bar{Z}$ & $\bar{p}$ \\
\hline \multirow{2}{*}{ Time Management } & Yes & 346 & 16.32 & 3.13 & \multirow{2}{*}{-6.744} & \multirow{2}{*}{$.000^{*}$} \\
\hline & No & 362 & 13.38 & 3.20 & & \\
\hline \multirow{2}{*}{ Communication } & Yes & 346 & 16.65 & 3.32 & \multirow{2}{*}{-4.252} & \multirow{2}{*}{$.007^{*}$} \\
\hline & No & 362 & 14.03 & 3.83 & & \\
\hline \multirow{2}{*}{ Leadership } & Yes & 346 & 18.78 & 3.55 & \multirow{2}{*}{-7.538} & \multirow{2}{*}{$.000^{*}$} \\
\hline & No & 362 & 15.26 & 3.37 & & \\
\hline \multirow{2}{*}{ Teamwork } & Yes & 346 & 22.89 & 4.21 & \multirow{2}{*}{-6.132} & \multirow{2}{*}{$.000^{*}$} \\
\hline & No & 362 & 19.21 & 4.43 & & \\
\hline \multirow{2}{*}{ Social Skills } & Yes & 346 & 15.36 & 3.33 & \multirow{2}{*}{-5.539} & \multirow{2}{*}{$.000^{*}$} \\
\hline & No & 362 & 13.65 & 4.05 & & \\
\hline \multirow{2}{*}{ Emotional Skills } & Yes & 346 & 15.87 & 3.37 & \multirow{2}{*}{-4.703} & \multirow{2}{*}{$.003^{*}$} \\
\hline & No & 362 & 13.40 & 3.63 & & \\
\hline \multirow{2}{*}{ Goal Setting } & Yes & 346 & 16.66 & 3.27 & \multirow{2}{*}{-5.648} & \multirow{2}{*}{$.000^{*}$} \\
\hline & No & 362 & 14.21 & 3.79 & & \\
\hline
\end{tabular}

Table-7. Analysis results of the study group according to the variable of playing in school teams (Mann Whitney U Test).

\begin{tabular}{|c|c|c|c|c|c|c|}
\hline \multicolumn{2}{|c|}{ Playing in School Teams } & \multirow{2}{*}{$\frac{\mathbf{N}}{203}$} & \multirow{2}{*}{$\begin{array}{c}\text { Mean } \\
17.98\end{array}$} & \multirow{2}{*}{$\frac{\text { SD }}{3.05}$} & \multirow{3}{*}{$\frac{\mathbf{Z}}{-8.803}$} & \multirow{3}{*}{$\frac{\mathbf{p}}{.000^{*}}$} \\
\hline \multirow{2}{*}{ Time Management } & Yes & & & & & \\
\hline & No & 505 & 14.30 & 3.53 & & \\
\hline \multirow{2}{*}{ Communication } & Yes & 203 & 16.87 & 3.43 & \multirow{2}{*}{-5.536} & \multirow{2}{*}{$.002^{*}$} \\
\hline & No & 505 & 14.25 & 3.42 & & \\
\hline \multirow{2}{*}{ Leadership } & Yes & 203 & 19.97 & 3.69 & \multirow{2}{*}{-8.682} & \multirow{2}{*}{$.000^{*}$} \\
\hline & No & 505 & 17.58 & 4.61 & & \\
\hline \multirow{2}{*}{ Teamwork } & Yes & 203 & 23.75 & 4.57 & \multirow{2}{*}{-6.571} & \multirow{2}{*}{$.000^{*}$} \\
\hline & No & 505 & 21.73 & 4.55 & & \\
\hline \multirow{2}{*}{ Social Skills } & Yes & 203 & 16.27 & 3.46 & \multirow{2}{*}{-5.437} & \multirow{2}{*}{$.002^{*}$} \\
\hline & No & 505 & 14.91 & 3.72 & & \\
\hline \multirow{2}{*}{ Emotional Skills } & Yes & 203 & 15.38 & 3.54 & \multirow{2}{*}{-4.663} & \multirow{2}{*}{$.004^{*}$} \\
\hline & No & 505 & 14.46 & 3.28 & & \\
\hline \multirow{2}{*}{ Goal Setting } & Yes & 203 & 16.55 & 3.04 & \multirow{2}{*}{-6.654} & \multirow{2}{*}{$.000^{*}$} \\
\hline & No & 505 & 15.01 & 3.46 & & \\
\hline
\end{tabular}

According to Table 7, in the analyses conducted for the variable of playing in school teams in the study group, it was determined that the differences in all of the subscales of life skills for sports were statistically significant $(\mathrm{p}<0.05)$

\section{Discussion and Conclusion}

In the current study, which investigated the effects of sports on the life skills of secondary school students, the results were discussed in the light of results in the literature.

According to the results of the study, it was determined that there were differences in the process of gaining and developing life skills according to the variable of the age of the study group in the current study, which covered children who were 10-14 years old. Accordingly, it was concluded that the children in the 14-years-old group had higher mean scores in the subscales of communication, time management, leadership, teamwork, emotional skills, and social skills. Several studies reported that individuals gained several life skills through sports. For example, it was revealed that young British individuals who participated in sportive activities learned life skills in teamwork, social skills, and leadership, interpersonal communication the most while learning life skills in emotional skills, problem-solving, decision making and time management the least (Buğan, 1999). Similarly, in studies conducted with Canadian (Brunelle et al., 2007; Strachan et al., 2011) American (Gould et al., 2007) and Australian (Vella, Oades, \& Crowe, 2013) athletes, coaches and parents, it was concluded that features of similar skills were learned. These findings suggest that young individuals learn more about certain life skills through sports compared to other life skills. In a study conducted by Türk (2015) the effects of sports on gaining life skills in young individuals were investigated with young individuals who were 14-18 years old and participated in basketball. In the study, it was concluded that there was no difference between ages in terms of gaining and developing life skills in young individuals. This study and the current study do not share similar results. However, the fact that each study in question covered different categories of ages in the sample groups could be the reason for these results. This is because age is a significant criterion in the process of gaining and developing life skills through sports. Additionally, it is believed that starting to participate in sports at an early age can lead to gaining life skills further. In the study, it was observed that there were differences in gaining life skills through sports according to the variable of gender. Accordingly, it was determined that there were statistically significant differences in all the subscales of life skills for sports in favor of females. The reasons for that are believed to be factors such as the events that females who participate in sports face during sports activities, friendship relationships, team games, and spectators. Certain studies in the literature support our study. Deniz (2002) investigated the levels of social skills in students who received university educations and concluded that female students were more competent in the subscales of emotional sensibility, cognitive expressionism and social control in social skill levels compared to male students while reporting that male students were more competent in the subscale of affective control compared to female students. In a study conducted by Cilingir (2006) social skills and problem-solving skills of regular high school and science high school students were compared. As a result of the 
study, it was observed that the students who received high school education experienced differences in their social skill levels according to their genders. In the sensory control subscale of social skills, it was concluded that males were more competent in terms of the ability to regulate and to control non-verbal messages and emotions compared to female students. In a study conducted by Balyan (2009) the attitudes of $2^{\text {nd }}$ stage primary school students and secondary education students toward physical education and sports lessons, social skills, and selfefficacy levels along with the relationships between those were investigated. As a result of the study, it was determined that there were statistically significant differences in attitudes toward physical education lessons according to the type of school, gender, sports facilities present in school and income levels. In social skill levels, it was determined that female students were at higher levels in positive social skills compared to males. The results of this study are also in parallel with the results of the current study.

In the analysis conducted based on the grade variable of the study group, it was determined that there were statistically significant differences in all the subscales of life skills for sports, except for the subscale of goal setting. Accordingly, the students who studied at $8^{\text {th }}$ grade learned life skills such as time management, teamwork, leadership, communication, social skills, emotional skills, and goal setting at higher levels compared to students who studied at $5^{\text {th }}, 6^{\text {th }}$ and $7^{\text {th }}$ grades. This indicates that the $8^{\text {th }}$ grade level in secondary education is a significant period that demands attention in terms of gaining and developing life skills. In a study conducted by Ryan and Dzewaltowski, similar results to our study were suggested and it was stated that the students at $6^{\text {th }}$ and $7^{\text {th }}$ grades improved their self-confidence through physical activities, dealt with problems in physical activities, encouraged others to gain a social circle of friends and acted assertive and outgoing (Larson, 2000; Ryan \& Dzewaltowski, 2002). This supports the results of our study. In the evaluation of previous studies, considering the role of sports in gaining and developing life skills, it can be stated that increasing the share of physical education and sports lesson in the secondary school curriculums, which prepare children for life and future, and including sportive activities more is a situation to which more importance and sensitivity should be attributed.

In the analysis conducted according to the variable of the family income level of the study group, it was determined that the differences in all of the subscales of life skills for sports were not statistically significant. It is believed that this is because sports can present everyone with equal opportunities regardless of their family income levels. What is important in sports is the will. Differences in income levels of families do not prevent athletes from gaining life skills. In Turkey, economic support at significant magnitudes is provided for sports. Especially, disadvantageous groups are supported via various projects on this subject. It is a commonly-known fact that individuals with disabilities participate and support and become successful. Here, the fundamental factor is the will and desire to participate in sports activities. Participation in these activities provides all children and young individuals with positive gains in their life skills. Previous studies in the literature support our study. For example, Mayer (1997) stated that the economic income of families did not have a significant effect on outputs regarding children while characteristics of parents, such as reliability and honesty, the health status of parents, and their skills were effective in the development of children. Furthermore, it was stated that there was no significant relationship between income levels and professions of families, and their socializing behaviors. These findings support our study. When the results of the study were evaluated, in the analysis conducted according to the status of exercising variable of the study group, it was observed that there were statistically significant differences in the subscales of life skills for sports. Accordingly, it was concluded that secondary school students who exercised gained more life skills, such as time management, leadership, communication, teamwork, emotional skills, social skills, and goal setting, compared to those who did not exercise. It was also determined that the students who played in school teams gained more life skills, such as communication, time management, leadership, social skills, teamwork, emotional skills, and goal setting, compared to those who did not play in school teams. It can be stated that this is because the social interaction of students with sports enables them to gain and to develop various life skills. In a study conducted by Reynolds et al. (1990) it was stated that sports positively affected quality life and other psychological variables while reporting that sports had positive effects on the expectancy of social competence, social factors, and stress, which are in parallel with our study. Another researcher stated that individuals who exercised had further tendencies for establishing communication compared to individuals who did not exercise (Ozerkan, 2004). Açak and Karademir (2011) discovered that there were statistically significant differences between the mean self-respect scores of individuals in favor of those who participated in sports according to the variable of participation in sports activities. In the analysis conducted according to the variable of playing in the school team of the study group, it was determined that the differences in all the subscales of life skills for sports were significant. The participation of students in the school team can provide positive effects for students in experiencing various behaviors of their friends, cooperating while setting common goals, controlling teamwork and behaviors, and creating opportunities to develop social and emotional skills. Researchers conducted a study that investigated the social skill levels of secondary school students who exercised and who did not exercise. When the results of this study were examined, no significant difference was determined in the subscales of "Positive Social Behavior" and "Negative Social Behavior" in the social skill levels in terms of the variable of "Licensed Sports Branch" in students. In other words, it was revealed that the status of practicing licensed sports or the difference in sports branches did not have any significant effect on their social skill levels in terms of "Positive Social Behavior" and "Negative Social Behavior" (Oztürk, 2018). Thus, sports can enable gains regardless of being practiced with a license or without a license. In a study conducted by another researcher, the levels of social skills were compared in secondary school students who did sports with licenses and who did not do sports. In the conclusion of the study, it was determined that there were significant differences between the social skill levels of the secondary school students who did sports with licenses and who did not do sports (Ozcan \& Yildırım, 2011). In other words, the subscale of affective sensitivity in life skill levels of students demonstrated significant differences according to the status of doing sports with licenses. When the differences between the status of exercising were examined, it was observed that there were differences in favor of students who did sports with licenses, which supports our study. When the results of this study were evaluated, it could be stated that the students who exercised gained more life skills compared to students who did not exercise. In conclusion, it was observed that the life skill features of individuals (communication, time management, leadership, teamwork, emotional skills, and social skills), who were 
10-14 years old and who exercised, in the secondary education period improved positively. It was further determined that sportive activities were more effective on female students compared to male students while playing in school teams provided more positive gains in life skill levels. Furthermore, when it is considered that the life skill levels of $8^{\text {th }}$-grade students were higher in the study, regardless of their family income levels, it can be stated that it is beneficial to encourage students to participate in sports and sports activities until reaching this period. This is because the life skills gained through sports in individuals should not be thought of as a situation that emerges instantly until reaching $8^{\text {th }}$ grade (approximately 14 years of age) and it should be noted that this emerges as an accumulation.

\section{References}

Açak, M., \& Karademir, T. (2011). Trainer evaluation scale for hearing impaired athletes. World Applied Sciences Journal, 14(5), 716-720.

Açak, M., \& Düz, S. (2018). Adaptation of life skills scale for sport into the Turkish culture. Inonu University Institute of Educational Sciences Journal, 5(9), 74-86.

Açak, M. (2006). Physical education teacher handbook. Ankara: Morpa Publication.

Avcıŏglu, H. (2005). Teaching social skills by activities (2nd ed.). Ankara: Root.

Balyan, M. (2009). The comparison of primary school 2nd level and elementary school students? attitudes towards physical education, social skills and self efficiency levels. Unpublished Doctoral Dissertation, Ege University Institute of Health Sciences, İzmir.

Botvin, G. J., \& Griffin, K. W. (2004). Life skills training: Empirical findings and future directions. Journal of Primary Prevention, 25(2), 211232.Available at: https://doi.org/10.1023/b:jopp.0000042391.58573.5b.

Brunelle, J., Danish, S. J., \& Forneris, T. (2007). The impact of a sport-based life skill program on adolescent prosocial values. Applied Developmental Science, 11 (1), 43-55.Available at: https://doi.org/10.1080/10888690709336722.

Buğan, M. (1999). Identifying mentally retarded women's acquisition of daily living skills. Unpublished Master's Thesis, Anadolu University Institute of Social Sciences, Eskişehir.

Burton, D., Naylor, S., \& Holliday, B. (2001). Goal setting in sport: Investigating the goal effectiveness paradox. In R. Singer, H. Hausenblas, \& C. Janelle (Eds.), Handbook of sport psychology. 497-528.

Camiré, M., Trudel, P., \& Forneris, T. (2009). High school athletes' perspectives on support, communication, negotiation and life skill development. Qualitative Research in Sport and Exercise, 1(1), 72-88.Available at: https://doi.org/10.1080/19398440802673275.

Caterino, M. C., \& Polak, E. D. (1999). Effects of two types of activity on the performance of second-, third-, and fourth-grade students on a test of concentration. Perceptual and Motor Skills, 89(1), 245-248.

Cilingir, A. (2006). The comparison between high school and high school of science students' social and problem solving skills. Unpublised Master's Thesis, Atatürk University İnstitute of Social Sciences, Erzurum.

Claessens, B. J., van Eerde, W., Rutte, C. G., \& Roe, R. A. (2007). A review of the time management literature. Personnel Revierw, 36(2), 255276.Available at: https://doi.org/10.1108/00483480710726136.

Cronin, L. D., \& Allen, J. (2017). Development and initial validation of the life skills scale for sport. Psychology of Sport and Exercise, 28, 105119.Available at: https://doi.org/10.1016/j.psychsport.2016.11.001.

Danish, S., Forneris, T., Hodge, K., \& Heke, I. (2004). Enhancing youth development through sport. World Leisure Journal, $46(3), 38-49$.

Deniz, M. (2002). A study of comparation of university students decision making strategies and social skill levels with respect to Ta-dominant ego states and some self qualities. Unpublished Doctoral Dissertation, Selçuk University Institute of Social Sciences, Konya.

Fraser-Thomas, J., \& Côté, J. (2009). Understanding adolescents' positive and negative developmental experiences in sport. The Sport Psychologist, 23(1), 3-23.Available at: https://doi.org/10.1123/tsp.23.1.3.

Gould, D., Collins, K., Lauer, L., \& Chung, Y. (2007). Coaching life skills through football: A study of award winning high school coaches. Journal of Applied Sport Psychology, 19(1), 16-37.Available at: https://doi.org/10.1080/10413200601113786.

Gould, D., Flett, R., \& Lauer, L. (2012). The relationship between psychosocial developmental and the sports climate experienced by underserved youth. Psychology of Sport and Exercise, 13(1), 80-87.Available at: https://doi.org/10.1016/j.psychsport.2011.07.005.

Holt, N. (2007). An ethnographic study of positive youth development on a high school soccer team. Paper presented at the Society For Research in Child Development Conference, Boston, MA.

Holt, N., Tink, L., Mandigo, J., \& Fox, K. (2008). Do youth learn life skills through their involvement in high school sport? A case study. Canadian Journal of Education, $31(2), 281-304$.

Humphrey, N., Kalambouka, A., Wigelsworth, M., Lendrum, A., Deighton, J., \& Wolpert, M. (2011). Measures of social and emotional skills for children and young people: A systematic review. Educational and Psychological Measurement, 71(4), 617-637.Available at: https://doi.org/10.1177/0013164410382896.

Judge, T. A., Bono, J. E., Erez, A., \& Locke, E. A. (2005). Core self-evaluations and job and life satisfaction: The role of self-concordance and goal attainment. The Journal of Applied Psychology, 90(2), 257-268.Available at: https://doi.org/10.1037/002 1-9010.90.2.257.

Larson, R. (2000). Toward a psychology of positive youth development. American Psychologist, 55(1), 170-183.Available at: https://doi.org/10.1037/0003-066x.55.1.170.

Mayer, S. (1997). What money can't buy: Family income and children's life changes. Cambridge, MA: Harvard University Press.

Onder, A. (2003). Educational drama applications for preschool children. Istanbul: Morpa.

Ozcan, G., \& Ylldırım, S. (2011). The comparison of social skill levels of student athletes in individual and team sports and student nonathletes in high school. Abant Izzet Baysal University journal of Social Sciences, 11(2), 111-135.

Ozerkan, K. (2004). Introduction to sports psychology. Basic concepts (1st ed., pp. 1-162). Ankara: Nobel Publishing.

Oztürk, Y. (2018). Making sport of middle school students according to the status of the investigation of the level of social skills. Sample of Kütahya Unpublised master's Thesis, Dumlupinar University Institute of Health Sciences, Kütahya.

Reynolds, K. D., Killen, J. D., Bryson, S. W., Maron, D. J., Taylor, C. B., Maccoby, N., \& Farquhar, J. W. (1990). Psychosocial predictors of physical activity in adolescents. Preventive Medicine, 19(5), 541-551.Available at: https://doi.org/10.1016/0091-7435(90)90052-l.

Rubin, R. B., \& Morreale, S. P. (1996). Setting expectations for speech communication and listening. New Directions for Higher Education, $1996(96), 19-29$.

Ryan, G. J., \& Dzewaltowski, D. A. (2002). Comparing the relationships between different types of self-efficacy and physical activity in youth. Health Education \& Behavior, 29(4), 491-504.

Strachan, L., Côté, J., \& Deakin, J. (2011). A new view: Exploring positive youth development in elite sport contexts. Qualitative Research in Sport, Exercise and Health, 3(1), 9-32.Available at: https://doi.org/10.1080/19398441.2010.541483.

Tel, M., \& Köksalan, B. (2008). Sociological investtigation of sport activities of lecturers (East Anatolian Sample). Journal of Social Science, 18 (1), 261, 18(1), 261-278.

Türk, A. (2015). The effect of to life skills achievement and development for young students: An analysis of '3x3 basketball tournemant. Unpublised Master's Thesis, Bahçeşehir University Institute of Social Sciences, İstanbul.

Vella, S. A., Oades, L. G., \& Crowe, T. P. (2013). The relationship between coach leadership, the coach-athlete relationship, team success, and the positive developmental experiences of adolescent soccer players. Physical Education and Sport Pedagogy, 18(5), 549-561.Available at: https://doi.org/10.1080/17408989.2012.726976.

World Health Organization. (1999). Partners in life skills education: Conclusions for a United Nations inter-agency meeting. Retrieved from http://www.who.int/mental_health/media/en/30.pdf. 